\title{
POCHODNE INSTRUMENTY FINANSOWE NOTOWANE NA HONG KONG EXCHANGES AND CLEARING LIMITED
}

Specjalny Region Administracyjny Hongkong położony we wschodniej Azji jest międzynarodowym centrum biznesu, handlu i finansów. Bazując na swej tradycyjnej polityce wolnego rynku i legislacyjnym dziedzictwie brytyjskiej kolonii, Hongkong rozwija się po przyłączeniu do Chińskiej Republiki Ludowej w 1997 r. w ramach

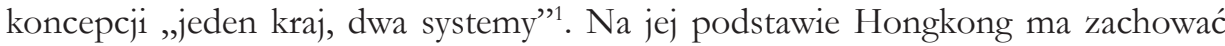
szeroką autonomię w sprawach ekonomicznych i społecznych przynajmniej do połowy XXI wieku². W ustawie zasadniczej (tzw. Basic Law) znalazły się regulacje dotyczące oddzielenia systemu ekonomicznego Hongkongu od Chin kontynentalnych i utrzymania jego wolnorynkowego charakteru. Ważna rola Hongkongu jako centrum finansowego znajduje odzwierciedlenie w dynamice wzrostu sektora usług finansowych ${ }^{3}$. Istotne znaczenie ma tutaj obrót instrumentami finansowymi na giełdzie Hong Kong Exchanges and Clearing Limited (HKEX).

W artykule omówiono rynek pochodnych instrumentów finansowych (derywatów) na Hong Kong Exchanges and Clearing Limited. Celem opracowania jest przedstawienie głównych instrumentów finansowych dostępnych na tej giełdzie oraz analiza ich rozwoju w latach 2013-2020. Teza badawcza opiera się na stwierdzeniu, że rynek pochodnych instrumentów finansowych na giełdzie Hong Kong Exchanges and Clearing Limited charakteryzuje się u progu trzeciej dekady XXI wieku bardzo dużą dynamiką rozwojową, jednak kilkukrotnie, na skutek kryzysu finansowego dynamika ta wyhamowała na kilka miesięcy. W artykule wykorzystano następujące metody badawcze: opisową, dokumentacyjną oraz statystyczna.

ORCID: 0000-0001-5722-9795, DOI: 10.4467/23538724GS.20.021.12139

1 Por. K. Żukrowska, Chiny: potencjat (gospodarczy, polityczny, militarny) jako instrument kształtowania nowego układu międżynarodowego, „Krakowskie Studia Międzynarodowe” 2018, nr 1, s. 34.

2 Y. Ghai, Hong Kong's New Constitutional Order: The Resumption of Chinese Sovereignty and the Basic Law, Hong Kong 1999, s. 231.

3 Por. E. Cieślik, Efek.t Smoka. Skutki ekspansji gospodarczej Chin po 1978 roku, Warszawa 2012, s. 83; eadem, Rozwój gospodarcsy Chin od roku 1978 do krysysu globalnego, Warszawa 2015, passim. 


\section{Charakterystyka Hong Kong Exchanges and Clearing Limited na tle innych giełd Chińskiej Republiki Ludowej}

Chiny odgrywają coraz istotniejszą rolę w kształtowaniu się globalnych rynków finansowych. Rozwój ekonomiczny kraju poprzez zbudowanie silnej realnej gospodarki i w efekcie zwiększającego się potencjału giełdowego zaplecza finansowego oraz inwestycyjnego stwarza nowe możliwości ${ }^{4}$. Szczególna rola w tym zakresie przypada giełdzie Hong Kong Exchanges and Clearing Limited.

Rynek akcji i obligacji na HKEX nieustannie się rozwija ${ }^{5}$. Jego udział zagraniczny cały czas wzrasta, próbując dorównać wysoko rozwiniętym gospodarkom. Jednak w Chinach oprócz HKEX funkcjonują jeszcze dwie tradycyjne giełdy specjalizujące się w notowaniach akcji i obligacji. Są to Shanghai Stock Exchange (SSE) i Shenzhen Stock Exchange (SZSE) ${ }^{6}$. Chiński rynek giełdowy pod względem wielkości zajmuje drugie miejsce na świecie. Wyprzedza go tylko rynek amerykański. Hong Kong Exchanges and Clearing Limited w XXI wieku rozwijała się w bardzo szybkim tempie. Giełda ta oferuje swoim klientom wszechstronna obsługę w obrocie akcjami i obligacjami. Dzięki efektywnemu systemowi samoregulacji oraz rozbudowanej technologicznie i nowoczesnej infrastrukturze komunikacyjnej zapewnia wysokie standardy obsługi oraz przyciaga wielu inwestorów zarówno krajowych, jak i zagranicznych. Pod względem kapitalizacji zajmuje piąte miejsce na świecie. Shanghai Stock Exchange zajmuje czwarte miejsce (drugie w Azji - po Japan Exchange Group Inc.), zaś Shenzhen Stock Exchange - siódme miejsce?

W tabeli 1 przedstawiono ranking najważniejszych giełd świata pod względem kapitalizacji. Dynamiczne zmiany zachodzące na Hong Kong Exchanges and Clearing Limited w latach 2016-2019 zaowocowały wzrostem liczby notowanych spółek. W 2016 r. liczba przedsiębiorstw wynosiła 1973, natomiast na koniec 2019 r. - 2449. Duże zainteresowanie spółek debiutem giełdowym na HKEX nie maleje. Co roku przybywa ponad sto nowych podmiotów. Dynamiczny rozwój znajduje odzwierciedlenie we wzroście kapitalizacji rynkowej.

4 China 2030 Building a Modern, Harmonious and Creative Society, World Bank, Development Research Center of the State Council, the People's Republic of China 2013.

5 E. Cerutti, M. Obstfeld, China's Bond Market and Global Financial Markets, IMF Working Paper, International Monetary Fund 2018, s. 4.

6 Szerzej: S. Antkiewicz, Pochodne instrumenty finansowe notowane na giełdach Chinskiej Republiki Ludowej, „Gdańskie Studia Azji Wschodniej” 2019, z. 16, s. 26.

7 World Federation of Exchanges, https://focus.world-exchanges.org/issue/april-2020/market-statistics (dostęp: 14.05.2020).

8 Hong Kong Exchanges and Clearing Limited, https://www.hkexgroup.com/About-HKEX/ Company-Information/ (dostęp: 30.04.2020). 
Tabela 1. Ranking dziesięciu największych giełd świata pod względem kapitalizacji (stan na 31.03.2020 r.)

\begin{tabular}{|l|c|}
\hline \multicolumn{1}{|c|}{ Nazwa giełdy } & Wartość kapitalizacji (mln USD) \\
\hline 1. NYSE & 25531662,9 \\
\hline 2. Nasdaq US & 11227006,1 \\
\hline 3. Japan Exchange Group Inc. & 5097673,4 \\
\hline 4. Shanghai Stock Exchange & 4672362,7 \\
\hline 5. Hong Kong Exchanges and Clearing & 4231959,7 \\
\hline 6. Euronext & 3669149,9 \\
\hline 7. Shenzhen Stock Exchange & 3275302,4 \\
\hline 8. LSE Group & 2917089,3 \\
\hline 9. TMX Group & 1746964,2 \\
\hline 10. Deutsche Boerse AG & 1578002,2 \\
\hline
\end{tabular}

Źródło: Opracowanie własne na podstawie danych z World Federation of Exchanges, https://focus. world-exchanges.org/issue/april-2020/market-statistics (dostęp: 14.05.2020).

Z kolei na Shanghai Stock Exchange notowana jest szeroka gama akcji i obligacji. Z roku na rok powiększa się oferta dostępnych produktów giełdowych. Na koniec 2019 r. na SSE były notowane akcje 1626 spółek, których obrót wyniósł 328 mld CNY. Całkowita liczba notowanych papierów wartościowych wynosiła $15186^{9}$. Natomiast na Shenzhen Stock Exchange na koniec 2019 r. notowane były akcje 2314 spółek $^{10}$. W ofercie występowało 8738 produktów, do których należą instrumenty finansowe z kategorii akcji, obligacji, funduszy inwestycyjnych oraz papierów wartościowych zabezpieczanych aktywami ${ }^{11}$. Postęp technologiczny regionu i całego kraju sprawił, że na giełdzie w Shenzhen są notowane przede wszystkim spółki nowych technologii ${ }^{12}$.

Jednak jedynie Hong Kong Exchanges and Clearing Limited może zostać uznana za giełdę uniwersalną, na której notowana jest zarówno szeroka gama instrumentów bazowych: akcji i obligacji, jak i duża grupa pochodnych instrumentów finansowych, a także derywatów towarowych. Dwie pozostałe giełdy papierów wartościowych, mające siedzibę w Chinach kontynentalnych, specjalizują się w notowaniach akcji i obligacji, a w ofercie posiadaja jedynie nieliczne opcje (SSE) lub nieco bardziej liczne kontrakty futures (SZSE).

\footnotetext{
9 Shanghai Stock Exchange, www.english2019.sse.com.cn (dostęp: 30.04.2020).

10 Shenzhen Stock Exchange, http://www.szse.cn/English/about/overview/index.html (dostęp: 26.03.2020).

11 J. Strzelecki, Giełda po chinsku, „Gazeta Bankowa” 2015, nr 10, s. 58.

12 I. Kujawa, Shen₹łen - miasto z. chiniskich snów, „Anthropos? Miasto i Miejsce” 2015, nr 24, s. 135.
} 


\section{Rozwój Hong Kong Exchanges and Clearing Limited}

Hongkong jest specjalnym regionem administracyjnym Chińskiej Republiki Ludowej położonym nad Morzem Południowochińskim. Ma długą i burzliwą historię kształtowania systemu sprawowania władzy. Został opanowany przez wojska brytyjskie podczas wojny opiumowej w latach 1839-1842. Po tej wojnie odłączono Hongkong od Chin i oddano jego terytorium Wielkiej Brytanii. Dopiero w roku 1984 zawarto umowę, dzięki której Chiny odzyskały utracone terytorium, gwarantując jednocześnie pozostawienie systemu administracyjno-prawnego przez kolejne pół wieku' ${ }^{13}$.

Od początku XX wieku Hongkong był jednym z największych i najważniejszych centrów finansowych na Dalekim Wschodzie. Razem z Singapurem i Szanghajem stanowił najbardziej znaczące ośrodki w całej Azji. Dzięki rozwojowi handlu, przemysłu i dużemu portowi miasto zaczęło przekształcać się w wielki ośrodek biznesowy. W związku z powstaniem w 1949 r. Chińskiej Republiki Ludowej i zachodzącymi zmianami spadła rola głównego regionalnego konkurenta Szanghaju, co umożliwiło przyciagnięcie większej liczby inwestorów i zyskanie pozycji lidera ${ }^{14}$. W latach 70 . XX wieku Hongkong został uznany za międzynarodowe centrum finansowe ${ }^{15}$.

Początki obrotu papierami wartościowymi na terenie Hongkongu datuje się na koniec XIX wieku. W 1891 r. stworzono pierwszy oficjalny rynek The Stockbrokers' Association of Hong Kong, który w 1914 r. przekształcił się w giełdę. W 1921 r. zostało założone drugie stowarzyszenie maklerów, które po II wojnie światowej połączyło się z istniejącym już rynkiem obrotu papierami wartościowy$\mathrm{mi}$, reaktywując notowania giełdowe po długoletnim konflikcie zbrojnym. Dynamiczny rozwój gospodarki Hongkongu skutkował powstaniem trzech kolejnych giełd: The Far East Exchange (1969), The Kam Ngan Stock Exchange (1971) oraz The Kowloon Stock Exchange (1972). W 1980 r. doszło do połączenia wszystkich czterech giełd w The Stock Exchange of Hong Kong Limited (SEHK). Kolejnym etapem rozwoju było powstanie w 1989 r. Hong Kong Securities Clearing Company Limited (HKSCC) ${ }^{16}$.

W 1999 r. władze Hongkongu, w celu zwiększenia konkurencyjności i dostosowania się do wymagań globalizującego się świata, zreformowały rynek akcji oraz instrumentów pochodnych. Nastapiło wówczas połączenie w jedną spółkę

\footnotetext{
13 E. Kajdański, Chiny. Leksylkon. Historia, gospodarka, kultura, Warszawa 2005, s. 89.

14 F. Wakeman, W. Yeh, Shanghai Sojourners, Berkley 1992.

15 I. Sobol, Mięzynarodowe centra finansowe [w:] Finanse miedżynarodowe: wybrane problemy, red. M. Markiewicz, U. Mrzygłód, Warszawa 2015, s. 175.

${ }^{16}$ Hong Kong Exchanges and Clearing Limited, https://www.hkexgroup.com/About-HKEX/ Company-Information/About-HKEX/History-of-HKEX-and-its-Market (dostęp: 30.04.2020).
} 
holdingowa giełd: The Stock Exchange of Hong Kong Limited oraz Hong Kong Securities Clearing Company Limited pod nazwą Hong Kong Exchanges and Clearing Limited (określana również jako Hong Kong Stock Exchange) ${ }^{17}$. Należy też odnotować, że w maju 2012 r. utworzono specjalną spółkę zależną OTC Clearing Hong Kong Limited, mającą na celu realizowanie funkcji rozliczeniowej dla instrumentów pochodnych.

W 2020 r. HKEX jest jedną z najbardziej rozwiniętych giełd na świecie. Dostęp do niej mają lokalne i zagraniczne podmioty gospodarcze oraz klienci indywidualni. Klasyfikuje się ją jako trzeci najbardziej znaczący rynek obrotu papierami wartościowymi w Azji, zaraz po Japan Exchange Group Inc. i Shanghai Stock Exchange. HKEX dba o rozbudowę, innowacje oraz wysoki stopień zaawansowania oferowanych produktów. Co roku poszerza swoją ofertę o innowacyjne instrumenty. Rozbudowywanie i unowocześnianie gamy dostępnych papierów wartościowych zachęca inwestorów do nabywania instrumentów.

Ważnym wydarzeniem na HKEX, będącym odpowiedzią na procesy globalizacji, było przejęcie w grudniu 2012 r. London Metal Exchange (LME). Historia Londyńskiej Giełdy Metali sięga 1877 r. Dynamiczny rozwój podczas rewolucji przemysłowej przyczynił się do ogromnego zapotrzebowania na metale. W ten sposób rozwinęły się kontrakty futures na metale. Od początku istnienia giełdy występowały w ofercie kontrakty na miedź oraz cynę. W 1920 r. wprowadzono do oferty kontrakty na ołów i cynk, w 1978 r. na aluminium, a rok później na nikiel. Przejęcie LME przez Hong Kong Exchanges and Clearing Limited stało się ważnym impulsem dla zwiększenia gamy dostępnych towarowych instrumentów pochodnych.

\section{Rozwój rynku akcji i obligacji notowanych na Hong Kong Exchanges and Clearing Limited}

Hong Kong Exchanges and Clearing Limited jest ważną giełdą, na której odbywa się obrót akcjami i obligacjami. W tabeli 2 przedstawiono rozwój rynku akcji na HKEX w latach 2013-2019. Pod względem liczby spółek giełda ciagle się rozwija w tempie ok. 6-7\% rocznie. Na koniec 2019 r. notowano na niej 2449 spółek. Ich kapitalizacja w analizowanym okresie rosła od wartości niewiele przekraczajacej 3 bln HKD w 2013 r. do blisko 5 bln HKD na koniec 2019 r. (jedynie w 2015 i 2018 r. odnotowano niewielkie zachwianie tendencji wzrostowej). Obroty akcjami w analizowanym okresie oscylowały pomiędzy 1,3 bln HKD a 2,4 bln HKD.

17 X. Lan, Let’s Buy Futures, „Beijing Review”, 21.06.2007. 
Tabela 2. Wartość obrotów akcjami i kapitalizacja na HKEX w latach 2013-2019

\begin{tabular}{|c|c|c|c|c|c|c|}
\hline Rok & $\begin{array}{c}\text { Wartość } \\
\text { obrotu } \\
\text { (mln HKD) }\end{array}$ & $\begin{array}{c}\text { Zmiana } \\
\mathbf{( \% )}\end{array}$ & $\begin{array}{c}\text { Kapitalizacja } \\
\text { (mln HKD) }\end{array}$ & $\begin{array}{c}\text { Zmiana } \\
\mathbf{( \% )}\end{array}$ & $\begin{array}{c}\text { Liczba } \\
\text { notowanych } \\
\text { spółek }\end{array}$ & $\begin{array}{c}\text { Zmiana } \\
\mathbf{( \% )}\end{array}$ \\
\hline 2013 & 1323825 & 18,46 & 3100777 & 4,74 & 1643 & 6,21 \\
\hline 2014 & 1521119 & 14,90 & 3233030 & 4,27 & 1752 & 6,63 \\
\hline 2015 & 2126259 & 39,78 & 3184874 & $-1,49$ & 1866 & 6,51 \\
\hline 2016 & 1351095 & $-36,46$ & 3193235 & 0,26 & 1973 & 5,73 \\
\hline 2017 & 1953138 & 44,56 & 4350514 & 36,24 & 2118 & 7,35 \\
\hline 2018 & 2342098 & 19,91 & 3819215 & $-12,21$ & 2315 & 9,30 \\
\hline 2019 & 1876727 & $-19,87$ & 4899234 & 28,28 & 2449 & 5,79 \\
\hline
\end{tabular}

Źródło: Opracowanie własne na podstawie danych Hong Kong Exchanges and Clearing Limited, https://www.hkex.com.hk/Market-Data/Statistics/ (dostęp: 30.04.2020).

Tabela 3. Wartość obrotów obligacjami i wartość nominalna emisji na HKEX w latach 2013-2019

\begin{tabular}{|c|c|c|c|c|c|c|}
\hline Rok & $\begin{array}{c}\text { Wartość } \\
\text { obrotu } \\
\text { (mln HKD) }\end{array}$ & $\begin{array}{c}\text { Zmiana } \\
\mathbf{( \% )}\end{array}$ & $\begin{array}{c}\text { Wartość } \\
\text { nominalna } \\
\text { obligacji } \\
\text { (mln HKD) }\end{array}$ & $\begin{array}{c}\text { Zmiana } \\
\mathbf{( \% )}\end{array}$ & $\begin{array}{c}\text { Liczba } \\
\text { notowanych } \\
\text { obligacji }\end{array}$ & $\begin{array}{c}\text { Zmiana } \\
\mathbf{( \% )}\end{array}$ \\
\hline 2013 & 575,57 & 31,37 & 74377,50 & 14,74 & 403 & 16,21 \\
\hline 2014 & 784,89 & 14,90 & 123967,02 & 66,67 & 640 & 58,81 \\
\hline 2015 & 1210,35 & 54,21 & 96868,18 & $-21,86$ & 762 & 19,06 \\
\hline 2016 & 2744,06 & 126,72 & 99894,00 & 3,12 & 892 & 17,06 \\
\hline 2017 & 7741,15 & 182,11 & 152359,43 & 52,52 & 1047 & 17,38 \\
\hline 2018 & 6179,55 & $-20,17$ & 134566,79 & $-11,68$ & 1195 & 14,14 \\
\hline 2019 & 7790,97 & 26,08 & 179963,34 & 33,74 & 1388 & 16,15 \\
\hline
\end{tabular}

Źródło: Opracowanie własne na podstawie danych Hong Kong Exchanges and Clearing Limited, https://www.hkex.com.hk/Market-Data/Statistics/ (dostęp: 30.04.2020).

W tabeli 3 przedstawiono rozwój rynku obligacji na HKEX w latach 20132019. Mimo że rynek ten cechuje się dużą tendencją wzrostową, jest on znacznie mniejszy od rynku akcji. Liczba notowanych obligacji rośnie bardziej dynamicznie niż liczba notowanych akcji. O ile jeszcze w 2013 r. na HKEX notowanych było czterokrotnie mniej obligacji niż akcji, o tyle na koniec 2019 r. różnica była zaledwie dwukrotna. Wartość nominalna notowanych obligacji oscylowała pomiędzy 74 mld HKD w 2013 r. a 180 mld HKD w 2019 r. Z kolei wartość obrotu dynamicznie rosła w analizowanym okresie od niespełna $600 \mathrm{mln}$ HKD w 2013 r. do blisko 8 mld HKD w 2019 r. Jedynie w 2018 r. odnotowano niewielkie załamanie tendencji 
wzrostowej. Należy jednak zauważyć, że wartość obrotu obligacjami była kilkaset razy mniejsza niż wartość obrotu akcjami.

\section{Klasyfikacja pochodnych instrumentów finansowych oferowanych na Hong Kong Exchanges and Clearing Limited}

Pochodne instrumenty finansowe (derywaty, ang. derivatives) sa to instrumenty finansowe, których cena jest zależna od ceny innych instrumentów określanych jako instrumenty bazowe (podstawowe) ${ }^{18}$. Ze względu na rodzaj instrumentu bazowego spośród instrumentów notowanych na Hong Kong Exchanges and Clearing Limited możemy wyróżnić następujące grupy:

- indeksowe instrumenty pochodne, których cena jest zależna od wartości indeksów akcji, np. kontrakty futures na Hang Seng Index (HSI), opcje na Hang Seng China Enterprises Index (HSCEI),

- akcyjne instrumenty pochodne oparte na kursach akcji pojedynczych spółek,

- procentowe instrumenty pochodne, których cena zależy od cen obligacji lub stóp procentowych, np. kontrakty futures na jednomiesięczną stopę procentową HIBOR,

- walutowe instrumenty pochodne opierające się na kursach walutowych, np. kontrakty futures na kurs USD/CNH, na kurs EUR/CNH,

- towarowe instrumenty pochodne, których cena zależy od cen towarów, np. kontrakty futures na złoto, kontrakty futures na London Metal Mini Futures.

Na Hong Kong Exchanges and Clearing Limited notowane są zarówno kontrakty futures (kontrakty terminowe), jak i opcje (kontrakty opcyjne). Kontrakty futures nie wymagają w chwili rozpoczęcia inwestycji zapłaty (poza niską prowizją maklerską i kaucją określaną mianem depozytu zabezpieczającego), jednak o ile inwestor, który prawidłowo przewidzi zmiany kursów instrumentu bazowego, odnotowuje znaczący zysk, o tyle w przypadku przeciwnego wobec przewidywań inwestora zachowania kursów uczestnik rynku odniesie stratę. Natomiast kontrakty opcyjne w momencie rozpoczęcia inwestycji wymagają wpłaty bezzwrotnej premii opcyjnej (poza niewielką prowizja maklerską i depozytem zabezpieczającym). W chwili zakończenia inwestycji inwestor, który prawidłowo przewidzi zmiany kursów instrumentu finansowego, odnotowuje znaczący zysk (pomniejszony w stosunku do kontraktów futures o wysokość premii), natomiast w przypadku przeciwnego wobec przewidywań inwestora zachowania kursów - uczestnik kończy inwestycję z wynikiem neutralnym.

18 S. Antkiewicz, Papiery wartościowe na rynku pienieżnym i kapitałowym, Warszawa 2012, s. 230. 
Opcje są bardziej skomplikowanym instrumentem pochodnym, stąd na Hong Kong Exchanges and Clearing Limited ich gama jest mniejsza niż oferta stosunkowo prostych kontraktów futures. Jednak zainteresowanie opcjami na HKEX jest wyższe niż kontraktami futures. Rynek instrumentów pochodnych jest najważniejszym rynkiem HKEX. Jego obroty przewyższają obroty łącznie analizowanego rynku akcji i obligacji.

\section{Rozwój rynku instrumentów pochodnych notowanych na Hong Kong Exchanges and Clearing Limited}

Hong Kong Exchanges and Clearing Limited jest jednym z najważniejszych miejsc, gdzie obywa się obrót pochodnymi instrumentami finansowymi. Od lat 80. XX wieku giełda ta była liderem w rejonie Azji i Pacyfiku. Do połowy lat 80. HKEX specjalizowała się w notowaniach kontraktów futures na produkty rolne i metale (np. cukier, bawełnę, soję, złoto). W dniu 6 maja 1986 r. do obrotu wprowadzono kluczowy Hang Seng Index Futures, który nadal jest jednym z najpopularniejszych kontraktów wykorzystywanych na HKEX.

Rynek instrumentów pochodnych na giełdzie w Hongkongu wzrasta z roku na rok w ustabilizowanym tempie. Giełda nieustannie rozbudowuje swoją szeroką ofertę, przyciagając inwestorów z całego świata. Notowane produkty są podzielone na pięć grup: walutowe, bazujące na stopie procentowej, towarowe, bazujące na kursach akcji pojedynczych spółek oraz indeksowe.

Pochodne instrumenty walutowe reprezentują: kontrakty futures USD/CNH, kontrakty futures EUR/CNH, kontrakty futures JPY/CNH, kontrakty futures AUD/ $\mathrm{CNH}$, kontrakty futures INR/CNH, kontrakty futures INR/USD, kontrakty futures $\mathrm{CNH} / \mathrm{USD}$, opcje USD/CNH.

Druga grupę stanowia instrumenty pochodne oparte na stopie procentowej. Należy tutaj wyróżnić kontrakty futures na jednomiesięczną stopę procentową rynku międzybankowego (One-Month HIBOR Futures) oraz kontrakty futures na trzymiesięczną stopę procentową rynku międzybankowego (Three-Month HIBOR Futures).

Trzecią grupa derywatów notowanych na HKEX są towarowe instrumenty pochodne. Zaliczają się do nich: kontrakty futures na złoto (rozliczane w USD oraz w $\mathrm{CNH}$ ), kontrakty futures na srebro (rozliczane w USD oraz w $\mathrm{CNH}$ ), kontrakty futures na London Metal Mini (rozliczane w USD oraz w CNH; dotyczą następujących metali: aluminium, cynku, miedzi, cyny, ołowiu, niklu) ${ }^{19}$, kontrakty futures na rudę żelaza ${ }^{20}$.

19 Por. H.G. Fung, Q. Wilson-Liu, Y. Tse, The information flow and market efficiency between the U.S. and Chinese aluminum and copper futures markets, ,Journal of Futures Markets” 2010, vol. 30.

20 Por. J. Tomaszewski, Rozwój rynku terminowego na giełdach towarowych w Chinach i jego powiazania ₹. globalnym rynkiem terminonym - analiza rynku kontraktów futures na metale przemystowe i szlachetne, „Finanse, Rynki Finansowe, Ubezpieczenia” 2017, nr 1, s. 558. 
Czwarta grupę stanowią instrumenty pochodne oparte na kursach akcji pojedynczych spółek. Wśród nich jest 80 kontraktów futures oraz 101 kontraktów opcyjnych. Bazują one na kursach największych spółek notowanych na Hong Kong Exchanges and Clearing Limited.

Ostatnią grupę derywatów stanowią kontrakty futures i kontrakty opcyjne bazujące na indeksach. Na koniec kwietnia 2020 r. na HKEX notowane były następujące pochodne instrumenty indeksowe: kontrakty futures na Hang Seng Index, kontrakty futures na Hang Seng Total Return Index, kontrakty futures na Mini Hang Seng Index, kontrakty futures na Dividend Index, kontrakty futures na HSI Volatility Index, opcje na Hang Seng Index, opcje na Weekly Hang Seng Index, opcje na Mini Hang Seng Index, kontrakty futures na Hang Seng China Enterprises Index, kontrakty futures na Hang Seng China Enterprises Total Return Index, kontrakty futures na Mini Hang Seng China Enterprises Index, opcje na Hang Seng China Enterprises Index, opcje na Weekly Hang Seng China Enterprises Index, opcje na Mini Hang Seng China Enterprises Index, kontrakty futures na MSCI Asia ex Japan Index, kontrakty futures na Sector Index, kontrakty futures na CES China 120 Index, kontrakty futures na BRICS Index ${ }^{21}$.

W tabeli 4 przedstawiono dane dotyczace wolumenu obrotów kontraktami futures oraz liczbę otwartych pozycji na tych kontraktach na Hong Kong Exchanges and Clearing Limited w okresie: styczeń 2013 r. - kwiecień 2020 r. Na giełdzie w Hongkongu występuje blisko dwukrotnie niższe zainteresowanie inwestowaniem w kontrakty futures niż nabywaniem opcji. Wolumen zawartych transakcji i liczba otwartych pozycji na kontrakty futures cechowały się dużą zmiennością. O ile w latach 2013-2014 można było zaobserwować powolny wzrost zainteresowania kontraktami futures, o tyle w roku 2015 przerodził się on w znaczącą hossę na tym instrumencie. W 2017 r. chińskie rynki finansowe dotknął największy od dekady kryzys finansowy, zatem widoczny jest on również w przypadku analizowanych kontraktów. Jednak w 2018 r. ponownie odnotowano bardzo duży wzrost zainteresowania kontraktami futures. Pod koniec 2019 r. pojawiły się pierwsze symptomy spadku wolumenu obrotów i liczby otwartych pozycji - być może należy to wiązać z pierwszymi komentarzami medialnymi, że Chinom może grozić zagrożenie epidemiologiczne wpływające na ewentualny spadek PKB.

W tabeli 5 przedstawiono dane dotyczące wolumenu obrotów kontraktami opcyjnymi oraz liczbę otwartych pozycji na tych kontraktach na Hong Kong Exchanges and Clearing Limited w okresie od stycznia 2013 r. do kwietnia 2020 r. Opcje sa na HKEX, w odróżnieniu od innych chińskich giełd, instrumentem zdecydowanie chętniej wykorzystywanym niż kontrakty futures. Od 2013 r. odnotowują one istotny

21 Hong Kong Exchanges and Clearing Limited, https://www.hkex.com.hk/Products/Listed-Derivatives/Equity-Index/Hang-Seng-Index-(HSI)/Hang-Seng-Index-Futures?sc_lang=e$\mathrm{n} \#$ \&product=HSI (dostęp: 30.04.2020). 
Tabela 4. Wolumen obrotów i liczba otwartych pozycji na kontraktach futures na HKEX w latach 2013-2020

\begin{tabular}{|c|c|c|c|c|}
\hline Rok & Wolumen & $\begin{array}{c}\text { Zmiana } \\
\mathbf{( \% )}\end{array}$ & $\begin{array}{c}\text { Liczba } \\
\text { otwartych } \\
\text { pozycji }\end{array}$ & $\begin{array}{c}\text { Zmiana } \\
\mathbf{( \% )}\end{array}$ \\
\hline 2013 & 51374854 & 9,46 & 427402 & 5,74 \\
\hline 2014 & 50379246 & $-1,94$ & 447895 & 4,79 \\
\hline 2015 & 73462212 & 45,82 & 617026 & 37,76 \\
\hline 2016 & 84100129 & 14,46 & 625456 & 1,37 \\
\hline 2017 & 77060327 & $-8,37$ & 507267 & $-18,90$ \\
\hline 2018 & 128847222 & 67,20 & 762823 & 50,38 \\
\hline 2019 & 115759091 & $-10,16$ & 659707 & $-13,52$ \\
\hline $01-04.2020$ & 43711942 & - & 645917 & $-2,09$ \\
\hline
\end{tabular}

Źródło: Opracowanie własne na podstawie danych Hong Kong Exchanges and Clearing Limited, https://www.hkex.com.hk/Market-Data/Statistics/Derivatives-Market?sc_lang=en (dostęp: 30.04.2020).

Tabela 5. Wolumen obrotów i liczba otwartych pozycji na kontraktach opcyjnych na HKEX w latach 2013-2020

\begin{tabular}{|c|c|c|c|c|}
\hline Rok & Wolumen & $\begin{array}{c}\text { Zmiana } \\
\mathbf{( \% )}\end{array}$ & $\begin{array}{c}\text { Liczba } \\
\text { otwartych } \\
\text { pozycji }\end{array}$ & $\begin{array}{c}\text { Zmiana } \\
\mathbf{( \% )}\end{array}$ \\
\hline 2013 & 78654010 & 7,94 & 5802680 & 17,95 \\
\hline 2014 & 92059793 & 17,04 & 7512511 & 29,47 \\
\hline 2015 & 116362151 & 26,40 & 6649954 & $-11,48$ \\
\hline 2016 & 104050543 & $-10,58$ & 8670654 & 30,39 \\
\hline 2017 & 137785021 & 32,42 & 10648503 & 22,81 \\
\hline 2018 & 167335854 & 21,45 & 9831914 & $-7,67$ \\
\hline 2019 & 147126707 & $-12,08$ & 9038844 & $-8,07$ \\
\hline $01-04.2020$ & 55011716 & - & 11146756 & 23,32 \\
\hline
\end{tabular}

Źródło: Opracowanie własne na podstawie danych Hong Kong Exchanges and Clearing Limited, https://www.hkex.com.hk/Market-Data/Statistics/Derivatives-Market?sc_lang=en (dostęp: 30.04.2020).

wzrost zainteresowania inwestorów zarówno w odniesieniu do wolumenu obrotów, jak i do liczby otwartych pozycji. W niektórych latach wzrosty te przekraczały 20\% (np. liczba otwartych pozycji w latach 2014, 2016, 2017 oraz wolumen obrotów w latach 2015, 2017, 2018). Co godne podkreślenia, w 2017 r. rynek opcji na HKEX dynamicznie rósł, podczas gdy w Chinach panował kryzys finansowy i inne giełdy odnotowywały spadki. Jak wspomniano, rynek kontraktów futures na HKEX 
w 2017 r. stracił swą dynamikę rozwojowa. Niewielkie spadki wolumenu obrotów opcjami i liczby otwartych pozycji zaobserwowano dopiero w 2019 r. (podobnie jak w przypadku kontraktów futures), co mogło wynikać z pogarszających się przewidywań co do rozwoju światowej gospodarki.

Zadziwiający jest jednak istotny wzrost zainteresowania opcjami w czterech pierwszych miesiącach 2020 r., czyli w okresie apogeum rozwoju epidemii COVID-19. $\mathrm{Na}$ koniec kwietnia 2020 r. liczba otwartych pozycji wzrosła o 23,32\% w stosunku do końca 2019 r., zaś wolumen 55,01 mln kontraktów zawartych w ciagu czterech pierwszych miesięcy 2020 r. można uznać za rekordowy. Może to wynikać z faktu, że inwestorzy prognozują, iż spadek PKB związany z epidemią COVID-19 nastapi szybko, ale nie są co do tego w pełni przekonani, dlatego decydują się korzystać z bezpieczniejszych instrumentów finansowych, jakimi są opcje, a unikają bardzo ryzykownych kontraktów futures.

W tabeli 6 przedstawiono wartość obrotu i wolumen oraz liczbę otwartych pozycji poszczególnych instrumentów pochodnych notowanych na HKEX. Biorąc pod uwagę wartość obrotu, największą popularnością cieszą się futures indeksowe (ok. 12-14 bln HKD) oraz futures walutowe (170-200 mld HKD). Natomiast pod względem wolumenu obrotów najczęściej wykorzystywane są futures indeksowe (112-126 mln kontraktów), opcje na akcje (106-126 mln kontraktów) oraz opcje indeksowe (38-40 mln kontraktów). Z kolei pod względem liczby otwartych pozycji najbardziej popularne są opcje na akcje (6-7 mln pozycji) i opcje indeksowe (2-3 mln pozycji). W przypadku większości instrumentów pochodnych można zauważyć lekki spadek zainteresowania w 2019 r. względem 2018 r. Nie dotyczy to jedynie kontraktów futures na akcje, futures na waluty, futures towarowych i opcji towarowych.

Tabela 6. Statystyki poszczególnych instrumentów pochodnych notowanych na HKEX w latach 2018-2019

\begin{tabular}{|c|l|r|r|c|}
\hline \multicolumn{1}{c|}{$\begin{array}{c}\text { Rodzaj } \\
\text { instrumentu }\end{array}$} & \multicolumn{1}{|c|}{ Wskaźnik } & $\mathbf{2 0 1 8}$ & $\mathbf{2 0 1 9}$ & Zmiana (\%) \\
\hline \multirow{5}{*}{ Opcje na akcje } & Wolumen & 125683652 & 106417826 & $-15,33$ \\
\cline { 2 - 5 } & $\begin{array}{l}\text { Wartość obrotu } \\
\text { (mln HKD) }\end{array}$ & 428612 & 358512 & $-16,36$ \\
\cline { 2 - 5 } & $\begin{array}{l}\text { Liczba otwartych } \\
\text { pozycji }\end{array}$ & 7111353 & 6624472 & $-6,85$ \\
\hline \multirow{3}{*}{ Futures na akcje } & Wolumen & 852238 & 894900 & 5,01 \\
\cline { 2 - 5 } & $\begin{array}{l}\text { Wartość obrotu } \\
\text { (mln HKD) }\end{array}$ & 3474 & 3767 & 8,43 \\
\cline { 2 - 5 } & $\begin{array}{l}\text { Liczba otwartych } \\
\text { pozycji }\end{array}$ & 19934 & 26986 & 35,38 \\
\hline
\end{tabular}




\begin{tabular}{|c|c|c|c|c|}
\hline $\begin{array}{c}\text { Rodzaj } \\
\text { instrumentu }\end{array}$ & Wskaźnik & 2018 & 2019 & Zmiana (\%) \\
\hline \multirow{3}{*}{ Opcje indeksowe } & Wolumen & 40026686 & 38297384 & $-4,32$ \\
\hline & $\begin{array}{l}\text { Wartość obrotu } \\
\text { (mln HKD) }\end{array}$ & 4206621 & 3807243 & $-9,490$ \\
\hline & $\begin{array}{l}\text { Liczba otwartych } \\
\text { pozycji }\end{array}$ & 2612803 & 2334663 & $-10,65$ \\
\hline \multirow{3}{*}{$\begin{array}{l}\text { Futures } \\
\text { indeksowe }\end{array}$} & Wolumen & 125840585 & 112193367 & $-10,84$ \\
\hline & $\begin{array}{l}\text { Wartość obrotu } \\
\text { (mln HKD) }\end{array}$ & 14242841 & 12319179 & $-13,51$ \\
\hline & $\begin{array}{l}\text { Liczba otwartych } \\
\text { pozycji }\end{array}$ & 708430 & 604284 & $-14,70$ \\
\hline \multirow{3}{*}{ Opcje walutowe } & Wolumen & 30067 & 15429 & $-48,68$ \\
\hline & $\begin{array}{l}\text { Wartość obrotu } \\
(\mathrm{mln} H \mathrm{HKD})\end{array}$ & 2979 & 1544 & $-48,17$ \\
\hline & $\begin{array}{l}\text { Liczba otwartych } \\
\text { pozycji }\end{array}$ & 5625 & 1643 & $-70,79$ \\
\hline \multirow{3}{*}{ Futures walutowe } & Wolumen & 1779895 & 1989408 & 11,77 \\
\hline & $\begin{array}{l}\text { Wartość obrotu } \\
(\mathrm{mln} H \mathrm{H} D)\end{array}$ & 175585 & 196056 & 11,66 \\
\hline & $\begin{array}{l}\text { Liczba otwartych } \\
\text { pozycji }\end{array}$ & 32284 & 24811 & $-23,14$ \\
\hline \multirow{3}{*}{$\begin{array}{l}\text { Futures i opcje } \\
\text { towarowe }\end{array}$} & Wolumen & 362956 & 658688 & 81,48 \\
\hline & $\begin{array}{l}\text { Wartość obrotu } \\
(\mathrm{mln} H \mathrm{H} D)\end{array}$ & 14435 & 27440 & 90,09 \\
\hline & $\begin{array}{l}\text { Liczba otwartych } \\
\text { pozycji }\end{array}$ & 1361 & 3175 & 133,28 \\
\hline \multirow{3}{*}{$\begin{array}{l}\text { Futures } \\
\text { procentowe }\end{array}$} & \begin{tabular}{|l|} 
Wolumen \\
\end{tabular} & 759 & 270 & $-64,43$ \\
\hline & $\begin{array}{l}\text { Wartość obrotu } \\
(\mathrm{mln} \text { HKD) }\end{array}$ & 119 & 42 & $-64,71$ \\
\hline & $\begin{array}{l}\text { Liczba otwartych } \\
\text { pozycji }\end{array}$ & 272 & 60 & $-77,94$ \\
\hline
\end{tabular}

Źródło: Opracowanie własne na podstawie danych Hong Kong Exchanges and Clearing Limited, https://www.hkex.com.hk/Market-Data/Statistics/Derivatives-Market?sc_lang=en (dostęp: 30.04.2020). 


\section{Podsumowanie}

W Chińskiej Republice Ludowej kilka giełd zajmuje się notowaniami akcji, obligacji i pochodnych instrumentów finansowych. Jednak większość z nich specjalizuje się w notowaniach konkretnej grupy instrumentów, pozostałe traktując jako uzupełnienie oferty. Jedynie Hong Kong Exchanges and Clearing Limited może być uznana za giełdę uniwersalną. Zajmuje ona istotną pozycję w zakresie notowań akcji i obligacji (na rynku chińskim ustępując jedynie Shanghai Stock Exchange), ale też jest najważniejsza giełdą w zakresie pochodnych instrumentów finansowych w ChRL.

Na koniec kwietnia 2020 r. na HKEX oferowanych było 8 kontraktów walutowych (7 futures i 1 opcja). Tego typu instrumenty nie są dostępne na żadnej innej giełdzie w ChRL. Ponadto na Hong Kong Exchanges and Clearing Limited notowane były 2 kontrakty futures oparte na stopie procentowej. Nieliczne instrumenty tej kategorii pojawily się także na China Financial Futures Exchange (kontrakty futures na obligacje dwuletnie TS, pięcioletnie TF i dziesięcioletnie T), jednak instrumentem bazowym w tym przypadku były ceny obligacji skarbowych, zależne od ich rentowności, nie zaś międzybankowa stopa procentowa, jak w odniesieniu do HKEX.

$\mathrm{Na}$ Hong Kong Exchanges and Clearing Limited notowane były również 4 kontrakty futures oparte na cenach towarów. Należy jednak przyznać, że część z nich to kontrakty typu London Metal Mini, a zatem występuje tutaj wiele podkategorii (kontrakty na aluminium, cynk, miedź, cynę, ołów, nikiel). Kontrakty oparte na cenach towarów stanowią jedyną grupę, w przypadku której na rynku chińskim HKEX nie jest liderem. Walory te są bowiem dostępne na następujących giełdach: Shanghai Futures Exchange (18 kontraktów futures i 3 kontrakty opcyjne); Dalian Commodity Exchange (19 kontraktów futures i 3 kontrakty opcyjne) i Zhengzhou Commodity Exchange (20 kontraktów futures i 4 kontrakty opcyjne).

Hong Kong Exchanges and Clearing Limited jest natomiast zdecydowanym liderem w dwóch ostatnich kategoriach. Na rynku tym notowanych jest bowiem 80 kontraktów futures oraz 101 kontraktów opcyjnych opartych na kursach największych spółek notowanych na Hong Kong Exchanges and Clearing Limited. Poza HKEX nieliczne opcje na akcje notowane sa jedynie na Shanghai Stock Exchange. Natomiast w zakresie kontraktów indeksowych na HKEX notowanych jest 12 kontraktów futures i 6 kontaktów opcyjnych. Nieliczne instrumenty tej kategorii notowane były jedynie na China Financial Futures Exchange: 3 indeksowe kontrakty futures: CSI 300 Index Futures (IF), CSI 500 Index Futures (IC), SSE 50 Index Futures (IH) oraz 1 opcja na indeks CSI $300^{22}$.

22 China Financial Futures Exchange, http://www.cffex.com.cn/en_new/CSI300IndexFutures (dostęp: 30.04.2020). 
Instrumenty pochodne stanowią więc główną grupę produktową dostępną na Hong Kong Exchanges and Clearing Limited. Dane pochodzące z raportów tej giełdy, dotyczące obrotów derywatami wykazują istotny wzrost zainteresowania ze strony inwestorów. Szybko rozwijająca się gospodarka chińska wymaga coraz nowszych metod zabezpieczających, co sprzyja poszerzaniu oferty HKEX o nowe instrumenty pochodne. Dodatkowo specyficzny system gospodarczy Hongkongu, odmienny niż w kontynentalnej części Chińskiej Republiki Ludowej, sprzyja wzrostowi zainteresowania inwestorów poszczególnymi kontraktami futures i opcyjnymi, co przejawia się wzrostem wolumenu obrotów i liczby otwartych pozycji.

\section{SUMMARY}

\section{THE MARKET OF DERIVATIVES ON THE HONG KONG EXCHANGES AND CLEARING LIMITED}

The paper presents the market of derivatives in Hong Kong. The constantly expanded, wide and standardized offer of derivatives increased its attractiveness and is attracting local and foreign investors. Among the range of quoted derivatives on the Hong Kong Exchanges and Clearing Limited, we can distinguish a lot of financial and a few commodity products.

At the end of April 2020 on the HKEX foreign exchange contracts (seven futures and one option), two futures based on interest rate and four futures based on the price of commodities were listed. Hong Kong Exchanges and Clearing Limited is on the first place in the offer of stock index contracts (eighty futures and one hundred one options) and single stocks (twelve futures and six options).

In spite of their complex and complicated form, derivatives are gaining more and more popularity on the Hong Kong Exchanges and Clearing Limited. Data from stock exchange market regarding derivatives trading showed the strong upward trend and the large interest from investors. The rapidly developing economy of Hong Kong is requiring more and more new hedging methods, which favours the extension of stock exchange offers with derivatives. The Hong Kong Exchanges and Clearing Limited achieves above-average turnover and increases in derivatives in terms of quantity. Additionally, the specific economic system of Hong Kong, which is quite different than in China is creating the growth of interest among investors as well as futures and options. The confirmation for this is the growth of turnover and the number of open positions. 